\title{
RESEARCH NOTE \\ Phenological cycle and floral development of Chloraea crispa (Orchidaceae)
}

\author{
Ursula Steinfort ${ }^{1}$, Mauricio A. Cisternas ${ }^{1,4}$, Rolando García ${ }^{2}$, Hermine \\ Vogel $^{3}$, and Gabriela Verdugo ${ }^{1}$ \\ 'Facultad de Agronomía, Pontificia Universidad Católica de Valparaíso. Casilla 4 D, Quillota, Chile. \\ ${ }^{2}$ Facultad de Ciencias Agrarias y Forestales, Universidad Católica del Maule. Avda. San Miguel 3605, Talca, Chile. \\ ${ }^{3}$ Facultad de Ciencias Agrarias, Universidad de Talca. Casilla 747, Talca, Chile.

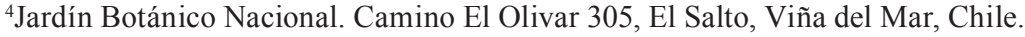

\begin{abstract}
U. Steinfort, M.A. Cisternas, R. García, H. Vogel, and G. Verdugo. 2012. Phenological cycle and floral development of Chloraea crispa (Orchidaceae). Cien. Inv. Agr. 39(2): 377-385. Chloraea crispa Lindl. is a terrestrial orchid endemic to Chile that has potential to be a novel alternative for the cut flower industry. The objectives of this study were to describe the phenological cycle and floral bud development of C. crispa to determine the timing of initiation and differentiation of the spike. During the summer, plants are dormant. The renewal buds are located at the top of the rhizome, next to the buds from which the shoot of the previous season originated. From the end of summer until the end of winter, the plant is in vegetative growth. From June onward, the flower stalk starts to emerge, and flowering and leaf senescence occur during the spring until the beginning of summer. The renewal buds started forming leaf primordia during or after the flowering of the above-ground annual stems and the senescence of the plant. Between December and January, the apical meristem changes to the reproductive stage, and from March, the first flower primordial could be observed. C. crispa shows similarity with other geophytes in which florogenesis and the development of new organs occurs within the renewal buds during or after the summer dormancy period.
\end{abstract}

Key words: Chilean orchid, Orchidaceae, geophyte, orchid florogenesis, orchid phenology, terrestrial orchid.

\section{Introduction}

The transition from the vegetative to the developmental stage is one of the most critical events in a plant's life cycle. Both genes and environmental factors control the initiation of flowering and the

Received July 5, 2011. Accepted January 30, 2012. Corresponding author: gabriela.verdugo@ucv.cl establishment of floral organs (Guo et al., 2008). Efficient flower production is the basis for the control of all factors that affect flowering, from floral induction to anthesis. The control of all factors that effect flowering from floral induction to anthesis is the basis for an efficient flower production. Thus, biological surveys are important to obtain knowledge of environmental factors that control the different steps of geophyte flowering (Le Nard and De Hertogh, 2002). 
Herbaceous perennial plants, especially geophytes that occur in climatic areas with marked seasons, show a strong adaptation to environmental changes (e.g., low and high temperatures, drought, etc.). These adaptations are primarily subterranean organs that enable survival under unfavorable conditions. Thus, in plant species with underground storage organs, the processes of organogenesis occurs inside the renewal buds, including cell division and elongation, the development of newly formed organs, etc. (Kamenetsky, 2008).

Geophytes are highly diverse with respect to botany, morphology and florogenesis, and the understanding of geophyte periodicity is essential for the control of flowering. In geophytes, the process of florogenesis and the development of floral organs are related to dormancy and takes place inside the renewal buds during or after the rest period, which is closely influenced by seasonal changes (De Hertogh and Le Nard, 1993; Toita et al., 2002; Flaishman and Kamenetsky, 2006).

Florogenesis in geophytes is divided into six different stages: induction, initiation, differentiation (organogenesis), floral stalk elongation, the maturation and growth of floral organs, and anthesis. These stages occur after the plant reaches the physiological age and size that are sufficient for blooming (Bernier et al., 1993; De Hertogh and Le Nard, 1993). Induction of flowering is determined by the genetic makeup of the species and environmental factors (Bernier et al., 1993). Flower initiation marks the end of leaf production and the start of reproductive development. Flower differentiation also involves the organogenesis of inflorescences, composed of individual flowers and flower parts. Finally, flower maturation consists of the growth of flower parts and the differentiation of reproductive tissues (Flaishman and Kamenetsky, 2006).

In the family Orchidaceae, floral anatomy has been studied extensively. In particular, floral development in this family has been investigated by many authors, especially as a tool for supporting phylogenetic studies (Rotor and MacDaniels,
1951; Schill et al., 1992; Kocyan and Endress, 2001; Kurzweil et al., 2005; Luo et al., 2005; Pabon-Mora and Gonzalez, 2008). However, floral development of the species of Chloraea and related genera remains poorly understood. Within the tribe Cranichideae (Orchidaceae), these taxa have distinctive floral traits, such as floral display and flower size and shape (Cisternas et al., 2012).

The orchid family in Chile is represented by 52 species in seven genera. Most of the species are rare, relatively unknown and endangered because of human activities that have dramatically reduced their distribution range (Novoa et al., 2006). Chloraea crispa Lindl. is a terrestrial orchid endemic to Chile (Novoa et al., 2006) and is distributed in coastal zones, in the Central valley, and in low elevation areas of the Coastal Cordillera from $38^{\circ} \mathrm{S}$ to $41^{\circ} \mathrm{S}$ (Humaña et al., 2008). C. crispa flowers from October to January (Novoa et al., 2006).

Characteristics of the spike, such as beautiful flowers, a long stem and long vase life, suggest that C. crispa has great potential as a novel alternative for the cut flower industry. The hybridization of selected individuals could enhance the potential for the commercialization of this species. However, for this flower to be a successful cultivar or source of cultivars, it is essential that we are able to predict and manipulate the induction of flowering.

The objectives of this study were to describe the phenological cycle and floral bud development of C. crispa under culture conditions to determine the initiation and differentiation of the spike such that the manipulation of flowering time could be elucidated for commercial flower growing.

\section{Materials and methods}

\section{Plant material and phenological observations}

C. crispa plants were collected in 2000 in the locality of Yumbel (province of Bio-Bio) $\left(37^{\circ} \mathrm{S} .72^{\circ}\right.$ $34^{\prime} \mathrm{W}$ ) and were grown in an open greenhouse in 
Quillota, region of Valparaíso (32 $52^{\prime}$ S. $71^{\circ} 14^{\prime} \mathrm{W}$ ), in the central zone of Chile, at an elevation of 128 masl. The climate of Quillota is characterized by cool winters (average temperatures in July $=5.5$ to $16.8^{\circ} \mathrm{C}$ ), hot dry summers (average temperatures in January $=11.5$ to $26.8^{\circ} \mathrm{C}$ ) and an average precipitation of $436.4 \mathrm{~mm}$ (Novoa et al., 1989). The plants were grown in 4-L pots containing $50 \%$ sand and $50 \%$ organic soil. The plants were watered twice a week during the period of vegetative growth and were fertilized and treated against diseases as required.

This species displays a basal leaf rosette, with $15 \mathrm{~cm}$ long and $2-3 \mathrm{~cm}$ wide leaves that senesce before or during anthesis. The rosette bears a spike covered by cauline leaves that, in the upper part, convert into bracts. The spike bears 6-20 attractive white flowers, composed of three sepals, one dorsal and two lateral, three petals, two lateral and one in the middle with a different form (called a labellum), and a column, which contains the androceum and the gynoecium (Figure 1) (Correa, 1969; Novoa et al., 2006). The roots are fleshy, fasciculate and arise from a rhizome (Cisternas et al., 2012).

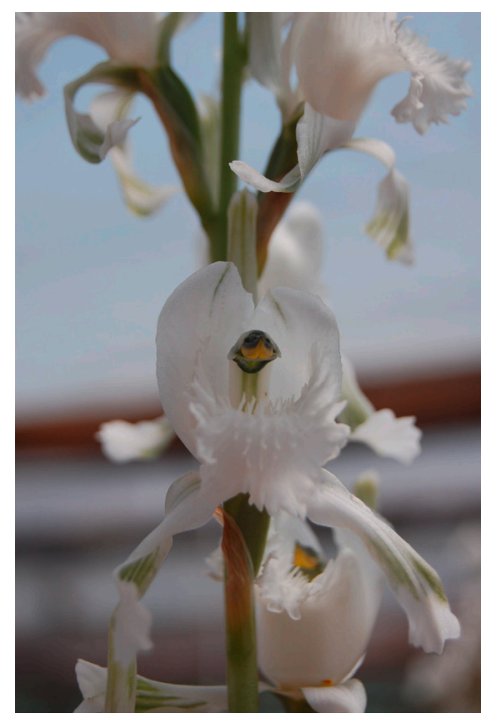

Figure 1. Chloraea crispa under greenhouse conditions in Chile. (Courtesy of A. Gonzalez, 2009).

Phenological observations were performed on 40 plants during 2008 and 2009, from the beginning of the vegetative cycle until they entered dormancy. Developmental stages were recorded monthly, and the number of leaves, the number of flower stalks and the number of flowers per stalk were recorded during the period of intensive growth from June - July until flowering in November - December.

\section{Microscopy}

The development of floral buds was studied monthly between January and July of 2008 and December and July of 2009, when the flower stalk began to arise. Ten plants, five of which that had flowered during the last season and five of which that had not, were utilized for histological cuts on each sampling date. Only the portion of the roots attached to the rhizome and stem were kept, and the rest of the tissues were discarded. For microscopic examination of the buds, rhizomes were fixed in FAA solution ( $50 \mathrm{~mL} 99.5 \%$ ethanol, $35 \mathrm{~mL}$ distilled water, $10 \mathrm{~mL}$ formalin and $5 \mathrm{~mL}$ glacial acetic acid). After fixation, the rhizomes were embedded in solid paraffin, and the blocks were cut with a rotatory microtome (model Minot, Johan) in longitudinal sections of 10 to $12 \mu \mathrm{m}$. The sections were mounted on slides, stained with safranine and light green and then examined and photographed under a microscope (Olympus CX 31 with Q imaging Micropublisher 3.3 RTV).

To complement the histological cuts and anatomical observations, additional individuals were collected and dissected near the apical meristem, which was exposed under a magnifying glass and fixed in FAA along with a portion of the rhizome for scanning electron microscopy. The samples were sending for preparation to the Departamento de Ciencias Vegetales, Facultad de Agronomia e Ingenieria Forestal, Pontificia Universidad Católica de Chile. Samples were washed in buffer, dehydrated in an ethanol series and dried in a critical point dryer with $\mathrm{CO}_{2}$ before mounting on slides and sputtercoating with Au-Pd. The samples were observed and photographed under an LEO 14VP scanning electron microscope. 


\section{Results}

General morphology and phenological cycle of the flowering plant

The sequence and timing of events during the development of $C$. crispa were similar in both growing seasons. This species usually flowers every two years, and its phenological cycle is described in Figure 2. In January and February (midsummer), the plants were dormant. The remains of leaves and flower stalks were easily observed above the surface. The underground perennial storage organ of C. crispa (the rhizome) developed a large number of perennial roots. New roots emerged from the periphery of the rhizome, leaving the old roots at the center to be replaced throughout the year. New roots developed after the flowering process, especially during autumn and winter. The roots varied greatly in number, length and diameter, with means of $16.5 \pm 11.6$, $78 \pm 47 \mathrm{~mm}$ and $7 \pm 2.4 \mathrm{~mm}$, respectively.

The renewal buds were located at the top of the rhizome, next to the buds from which the previous season's shoot originated, and produced leaves or leaves and a flowering stem in the following growing period. In this species, there is a marked apical dominance, which is usually overcome after the plant flowers for the first time. Moreover, this species has a sympodial growth pattern that can play an important role in an aspect of the plant architecture.

From the end of February until the middle of August, C. crispa grows vegetatively. Most vegetative growth occurs during autumn and winter. The plant has 3-24 leaves per shoot that are maintained until senescence. The leaves are lanceolate, fleshy and wide at the base, with a brilliant green color, and form a basal rosette.

From June to August, the flower stalk emerged from the center of the rosette. The flower stalk is very consistent at the base, reduces in size near the apex and is covered with caulinary leaves of a lighter green than the rosette leaves. The flowering process can last approximately six weeks and occurs between the last week of September and mid-December, simultaneously with the formation of fruits and the start of senescence (October-February).

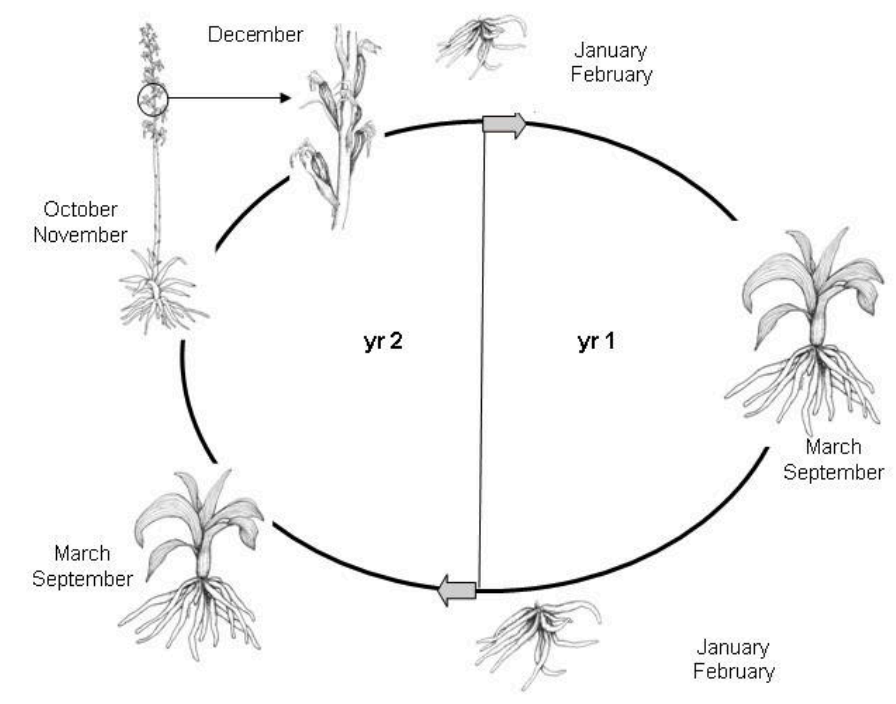

Figure 2. Phenological cycle of Chloraea crispa under greenhouse conditions in Chile. (Courtesy of A. Gonzalez, 2009). 
Each plant produced a mean of 1.3 flower stalks, with a mean total length of $81.70 \pm 23.27 \mathrm{~cm}$. The inflorescence had a mean total length of $29.98 \pm 14.11$ $\mathrm{cm}$ and was composed of $15.25 \pm 8.03$ flowers, on average, which opened acrotonically from base to top and were helicoidally arranged, each of which were covered by a bract. The first flower was fully opened when the flowers located in the middle of the inflorescence were just coming out of the bract and the apical flowers were still completely covered. Five to seven days elapsed between the opening of the first and second flowers; however, flowers located at the center of the stalk opened faster. The flower bud of the apex was usually aborted.

In October, the first signs of leaf senescence were visible. Basal leaves changed color from green to orange or brown at the apex of the leaves. All of the leaves were lost between December and January. Senescence of the flower stalks and leaves occurred simultaneously. The flower stalk commenced senescence when the first opened flower and bract turned brown and became dehydrated. However, flowers were still in good condition after the leaves died completely, approximately a month later.

\section{Bud and floral development}

Development of the monocarpic shoot in the renewal bud of $C$. crispa began with the formation of leaf primordia, during or after the flowering of the above-ground annual stems and the senescence of the plant (Figure 3A); the plants at this stage had a flat apical meristem. Between December and January, the apical meristem changed to a dome shape, when the floral initiation stage began. The first flower primordia were observed in March (Figures 3B and C), and the first inflorescences (Figure 3D) were detected at the end of April. The floral primordia developed inside the base of the bracts of the inflorescence and resembled a protuberance of meristematic tissue in a dome shape (Figure 4A). In the central part of the floral meristem, there was a central depression in which the primordia of the dorsal sepal and the two lateral sepals developed. The next structures that differentiated in the flower primordia were the two lateral petals, the middle petal or labellum, which is located between the primordia of the lateral sepals and could be easily identified in June, and the column, which contains the androeceum and gynoecium (Figure 4B).

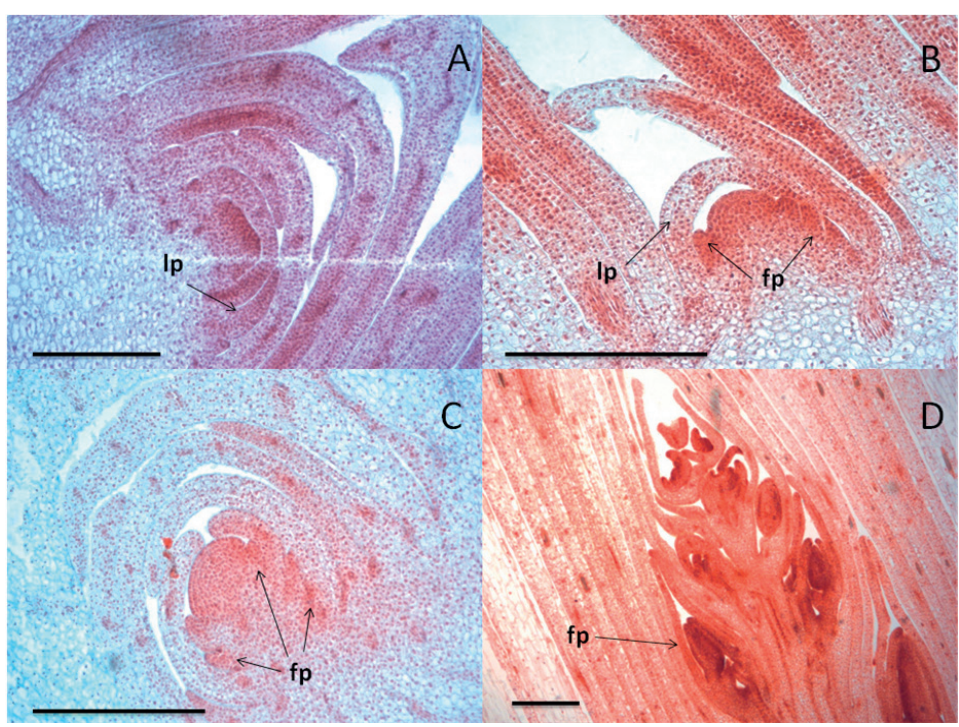

Figure 3. Floral development of C. crispa under light microscopy. (A) January, vegetative meristem with leaf primordia (lp). (B) March, generative meristem with flower (fp) and leaf primordia (lp). (C) June, generative meristem with several flower primordia (fp). (D) July, development of the inflorescence. Bar $=0.5 \mathrm{~mm}$. 


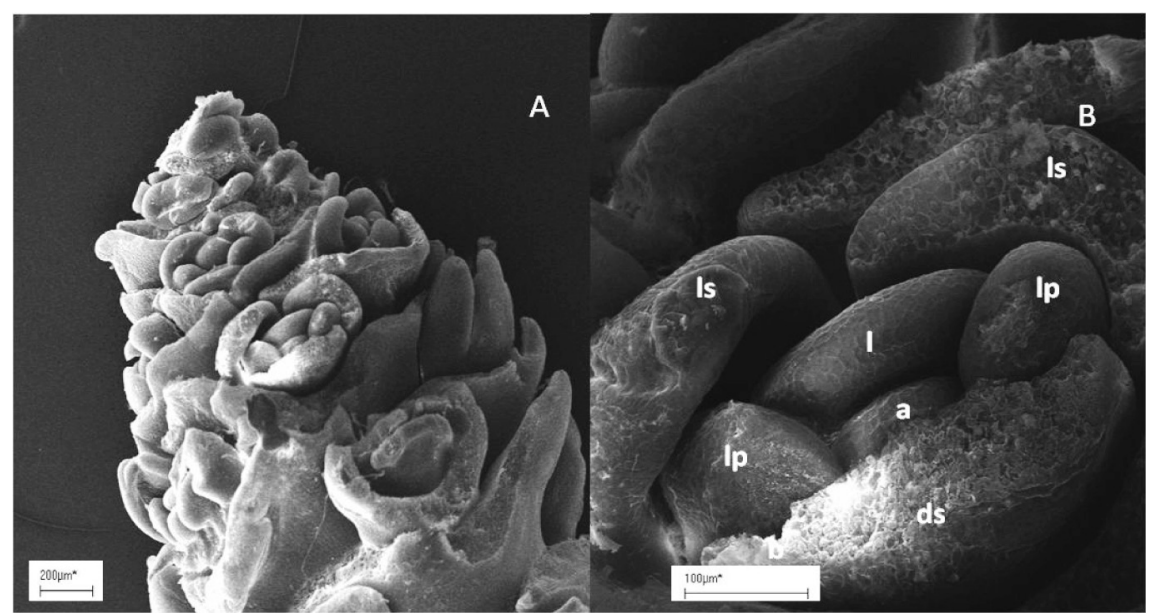

Figure 4. Floral development of Chloraea crispa under scanning electron microscopy (SEM). Bracts were removed. (A) Differentiation of flower primordia on the inflorescence. (B) Detail of flower primordia, lateral sepals (1s), dorsal sepal (ds), lateral petals (lp), labellum (1), anther (a) and bracts (b). (Courtesy of A.M. Mujica, 2009).

\section{Discussion}

Geophytes are usually found in climatic areas with marked seasonal changes. Periods of high and low temperatures and drought lead to the development of specialized anatomical structures and annual life cycles with periods of growth and dormancy (Flaishman and Kamenetsky, 2006). A morphological analysis of $C$. crispa reveals its similarity with other geophytes that have a thermoperiodic life cycle. A perennial rhizome permits the accumulation of storage products and plant renewal (De Hertogh and Le Nard, 1993). In adult plants of C. crispa, several buds are formed in the upper portion of the rhizome and near the base of the above-ground stems. Some of these buds will develop shoots in the next growth period, which in nature coincides with the beginning of rain during autumn (with a 11-hour light/13-hour dark photoperiod). In this species, the transition from a vegetative to a reproductive stage, with the characteristic dome shape of the reproductive meristems, can be observed under cultivation in the summer dormancy period from December and January onward. This result agrees with those of other geophytes in which florogenesis and the development of new organs are associated with dormancy and occur within the renewal buds during or after the rest period (Flaishman and Kamenetsky, 2006). Floral differentiation continues through autumn, and the floral stalk elongation can be observed from June onwards, prior to anthesis at the end of September and full blossom from October to late November (with a long day photoperiod of 13-14 hours of light and 10-11 hours of dark).

The flowering process is a clear example of the strong interaction between plants and their environment; in Quillota ( $32^{\circ} 52^{\prime} \mathrm{S} .71^{\circ} 14^{\prime} \mathrm{W}$ ) orchids, the flowering period extends from the end of September to December and is usually 3-4 weeks before that of Yumbel $\left(37^{\circ} \mathrm{S} .72^{\circ} 34^{\prime} \mathrm{W}\right)$, where the first specimens were collected (Humaña et al., 2008).

If the transition from a vegetative to a reproductive stage starts between December and January, floral induction in C. crispa must occur before, during or shortly after the current flowering season. Unfortunately, the mechanism that stimulates flower induction in C. crispa is still unknown, unlike other geophytes of economic importance. Flower induction is greatly affected by the genetic makeup of individual plant species and by environmental factors (Flaishman and Kamenetsky, 2006). The most important environmental factors controlling 
flowering time are the photoperiod (Corbesier et al., 1996), low temperatures (Michaels and Amasino, 2000), and water availability (Bernier et al., 1993). Flowering is also promoted by gibberellins (Mutasa-Gottgens and Hedden, 2009). Explaining the flowering cycle by a direct cause is not possible. We initially dismissed an isolated effect from the photoperiod because we observed floral differentiation (in autumn with short day) and flowering (in spring with long day) over an observed cycle of 2 years. However, it is possible that there is a thermal sequence involved in the process, as in other geophytes, and temperature is likely the most important factor that affects the timing and rate of flower initiation and development. In addition, the availability of water during C crispa cultivation did not change because the irrigation regime was twice a week $(20 \mathrm{~mL}$ of water per plant).

Most of the work related to the control of flowering in orchids has been performed in epiphytic orchids, such as Zygopetalum, Miltoniopsis, Dendrobium and Cattleya, in which a combination of short days and low temperatures usually stimulates flowering (Lopez and Runkle, 2005). For example, in Odontodia hybrids, constant temperatures between 14 and $17^{\circ} \mathrm{C}$ and the size of the pseudobulb determine their ability to flower (Blanchard and Runkle, 2008), and in the Zygopetalum Redvale "Fire Kiss" orchid, short days of nine hours followed by temperatures between 11 to $14{ }^{\circ} \mathrm{C}$ stimulate flowering (Lopez et al., 2003). However, differences might be expected in terrestrial orchids, which are not similar to epiphytic orchids, and the mechanisms related to the promotion of flowering in these orchids are unknown.

The phenological cycle of C. crispa must be considered for commercial production, and further studies related to flower induction and promotion must be performed to develop this species into a new flower or pot plant crop. This is especially important because only a small percentage (20 to $25 \%$ ) of the plants can flower every year, and most of the individuals flower every two years. In the flower industry, people are always looking for novelties, but biannual flowering may be a threat to the commercial success of this plant.

\section{Acknowledgments}

We thank FIA PI-C-2007-1-A-003 for the funds that supported this investigation, Edith Mendez, Claudia Gaete and Patricia Peñaloza (P. Universidad Católica de Valparaiso) for technical assistance and support on light microscopy, Ana Maria Mujica, for the preparation and fotographs of the SEM samples, Alvaro Gonzalez, who provided the picture and drawings of C. crispa, and Carlos Medina-Torres for English revisions.

\section{Resumen}

U. Steinfort, M.A. Cisternas, R. García, H. Vogel y G. Verdugo. 2012. Ciclo fenológico y desarrollo floral de Chloraea crispa (Orchidaceae). Cien. Inv. Agr. 39(2): 377-385. Chloraea crispa Lindl. (Orchidaceae) es una orquídea terrestre endémica de Chile, con potencial como nueva alternativa para la industria de flor de corte. Los objetivos de este estudio fueron describir el ciclo fenológico y el desarrollo de yemas florales de C. crispa de manera de determinar el comienzo de la iniciación floral y la diferenciación de la vara floral. Durante el verano las plantas se encontraron en dormición, las yemas de renuevo se localizaron en la parte superior del rizoma, cercanas a las yemas que originaron el crecimiento de la temporada anterior. Desde finales del verano hasta el final del invierno, las plantas se encontraban en crecimiento vegetativo. Desde junio en adelante el tallo floral comenzó a emerger. La floración junto con la senescencia de las hojas ocurrió durante la primavera hasta los comienzos de verano. Las yemas de renuevo comenzaron la formación de primordios foliares, durante o después de la 
floración de los crecimientos de la temporada y senescencia de la planta. Entre diciembre y enero, el meristemo apical cambió al estado reproductivo y desde marzo en adelante fue posible observar los primeros primordios florales. C. crispa presenta similitudes con otras geófitas, donde la florogénesis y el desarrollo de nuevos órganos ocurre al interior de las yemas de renuevo durante o después del periodo de dormición estival.

Palabras clave: desarrollo floral, fenología orquídea, geófita, Orchidaceae, orquídea, orquídea chilena, orquídea terrestre.

\section{References}

Bernier, G., A. Havelange, C. Houssa, A. Petitjean, and P. Lejeune. 1993. Physiological signals that induce flowering. The Plant Cell 5: 1147-1155.

Blanchard, M.G., and E.S. Runkle. 2008. Temperature and pseudobulb size influence flowering of Odontioda orchids. Hortscience 43: 1404-1409.

Cisternas, M.A, G. Salazar, G. Verdugo, P. Novoa, X. Calderon, and M. Negritto. 2012 Phylogenetic analysis of Chloraeinae (Orchidaceae) based on plastid and nuclear DNA sequences. Botanical Journal of the Linnean Society doi:10.1111/ j.1095-8339.2011.01200.x

Corbesier, L., I. Gadisseur, G. Silvestre, A. Jacqmard, and G. Bernier. 1996. Design in Arabidopsis thaliana of a synchronous system of floral induction by one long day. Plant Journal 9: 947-952.

Correa, M., 1969. Chloraea género sudamericano de Orquidaceae. Darwiniana 15: 374-500.

De Hertogh, A., and M. Le Nard. (eds.). 1993. Bulb growing and development and flowering. Elsevier, Amsterdam.

Flaishman, M., and R. Kamenetsky. (eds.). 2006. Florogenesis in flower bulbs: classical and molecular approaches Global Science Books, Japan.

Guo, B., T. Zhang, J.L. Shi, D.H. Chen, D.L. Shen, and F. Ming. 2008. Cloning and characterization of a novel PI-fike MADS-box gene in Phalaenopsis orchid. DNA Sequence 19: 332-339.

Humaña, A., M.A. Cisternas, and C.E. Valdivia. 2008. Breeding system and pollination of selected orchids of the genus Chloraea (Orchidaceae) from central Chile. Flora 203: 469-473.

Kamenetsky, R. 2008. Florogenesis in geophytes: Classical and molecular approaches. In: J. E. Van den Ende, and H. Gude (eds.). Book of Abstracts. 10th Intl. Symp. On Flower Bulbs and Herbaceous Perennials. Lisse, The Netherlands. p. 20.

Kocyan, A., and P.K. Endress. 2001. Floral structure and development of Apostasia and Neuwiedia (Apostasioideae) and their relationships to other Orchidaceae. International Journal of Plant Sciences 162: 847-867.

Kurzweil, H., P.H. Weston, and A.J. Perkins. 2005. Morphological and ontogenetic studies on the gynostemium of some Australian members of Diurideae and Cranichideae (Orchidaceae). Telopea 11: 11-33.

Le Nard, M. and A.A. De Hertogh. 2002. Research needs for flower bulbs (geophytes) Acta Hort. 570: 121-127.

Lopez, R.G., and E.S. Runkle. 2005. Environmental physiology of growth and flowering of orchids. Hortscience 40: 1969-1973.

Lopez, R.G., E.S. Runkle, R.D. Heins, C.M. Whitman. 2003. Temperature and photoperiodic effects on growth and flowering of Zygopetalum Redvale 'Fire Kiss' orchids. In: Blom, T., and R. Criley (eds.). Elegant Science in Floriculture. p. 155-162.

Luo, Y.B., G.H. Zhu, and H. Kurzweil. 2005. The gynostemium of Hemipiliopsis purpureopunctata and Senghasiella glaucifolia, two taxonomically disputed species of Habenariinae (Orchidaceae). Botanical Journal of the Linnean Society 147: 191-196.

Michaels, S.D., and R.M. Amasino. 2000. Memories of winter: vernalization and the competence to flower. Plant Cell and Environment 23: 11451153.

Mutasa-Gottgens, E., and P. Hedden. 2009. Gibberel- 
lin as a factor in floral regulatory networks. Journal of Experimental Botany 60: 1979-1989.

Novoa, P., Espejo, J., Cisternas, M., Rubio, M., Dominguez, E. (Eds.), 2006. Guia de campo de las orquideas chilenas. Corporacion chilena de la madera, Concepcion.

Novoa, R., S. Villaseca, P. Del Canto, J. Rouanet, C. Sierra, and A. Del Pozo (eds.). 1989. Mapa agroclimático de Chile. Santiago.

Pabon-Mora, N., and F. Gonzalez. 2008. Floral ontogeny of Telipogon spp. (Orchidaceae) and insights on the perianth symmetry in the family. International Journal of Plant Sciences 169: 1159-1173.
Rotor, G., and L.H. MacDaniels. 1951. Flower bud differentiation and development in Cattleya labiata Lindl. American Journal of Botany 38: 147-152.

Schill, R., C. Dannenbaum, and C. Eckert. 1992. On the floral development in Thecostele alata (Roxb) Par and Rchb F 1847 (Orchidaceae). Flora 186: 271-285.

Toita, E.S., P.J. Robbertsea, and J.G. Niederwieser. 2002. Effects of growth and storage temperature on Lachenalia cv. Ronina bulb morphology. Scientia Horticulturae 94: 117-123. 
